\title{
Wage Effects of Education, Work Experience, Skills, Migration Status and Industry in Canada - Results from PIAAC
}

\author{
Silvia Annen \\ University of Toronto (OISE), Canada
}

\begin{abstract}
The following results derive from a project, which aims to analyse the labour market outcomes of migrants in comparison to native born Canadians. Within this project a mixed methods approach is used - including quantitative analyses of the PIAAC data set, as well as qualitative case studies of Canadian enterprises and expert interviews. In doing so, the usability of foreign qualifications and skills in the labour market is evaluated. The theoretical background is formed by human capital theory - reflecting it critically.

This paper uses the Canadian PIAAC data 2012 to analyse the impact of the aspects education, work experience, skills, migration status and industry on individual wages. The analyses refer to the Mincerian wage regression model. The results show the positive income effects of educational attainment and work experience as well as the mostly negative effect of migration. Furthermore, the results prove the significant role industry plays regarding the differentiation of wages.
\end{abstract}

\section{Introduction}

Canadian Society is characterised by a plurality of immigrants. Data from the 2011 National Household Survey show that $22 \%$ of the Canadian population aged between 16 and 65 years were born abroad. While immigrants historically mainly came from Europe, currently Asia is the most frequent region of origin. By implementing the points system in 1967 the Canadian migration policy focused mainly on economic criteria [1]. Thus, more migrant labourers came to Canada than people migrating because of family reasons or refugees [2]. Furthermore, the evaluation of individual immigrants within the Canadian points system and fluent language skills in English or French have positive labour market effects [3]. At present, the Canadian migration policy and the corresponding recognition approaches are still strongly geared to economic criteria as well as to qualifications and skills.

The efficiency and performance of the Canadian selection system is consistently been discussed critically $[4 ; 5 ; 6]$. Several studies document the deterioration of the labour market outcomes of qualified immigrants, which is reflected in comparatively lower incomes, higher unemployment rates, a devaluation of skills as well as an economic marginalisation [7], [8], [9], [10].

When analysing the usability of foreign qualifications and competences, skill underutilization and pay inequity have to be distinguished - both are forms of employment discrimination of immigrants and pose significant challenges in Canada. In contrast to pay inequity, few studies have addressed the incidence of skill under-utilization [11]. Existing studies on the recognition of foreign qualifications and related income effects often use census data, but also other sources like the Ethnic Diversity Survey or the Longitudinal Survey of Immigrants to Canada. On the macro-level income differences and overeducation of immigrants have been mainly explained by the imperfect transferability of human capital across country borders. Transferability depends on, how closely the country of origin compares to the host country in terms of economic conditions, educational systems, industrial structure, institutional settings, language, etc. [12].

Further studies prove the devaluation of immigrants' human capital - especially lower payment for foreign work experience (most notably if not gained in Europe or North America) [13; 14]. Schaafsma and Sweetman verify a relation between the age at the time of migration and income as well as acquired educational level [14].

Aydemir and Skuterud provide evidence that one third of the difference of entry salaries of immigrants in comparison to native born Canadians can be explained by language skills and country of origin [15]. This difference is attributed to lack of recognition of foreign work experience [15]. Li also arrives at the conclusion that income differences can be largely explained by the varying human capital and work experience of immigrants [12]. Owen and Lowe use a qualitative approach to gain insights about the reasons for existing income differences [16].

Many studies use census data or other data sources that do not contain acquisition of the foreign qualifications information. The PIAAC (Programme for the International Assessment of Adult Competencies) data include this information, allowing for the examination of differences between qualifications from differing origin countries. 
Besides taking into account skills individually, interactions between different skills can also have relevant influence on income. In this regard Warman, Sweetman and Goldmann provide results which suggest that the rate of return on education is positively related to literacy skills (in English or French), but in contrast there is no positive relation to the rate of return on pre-migration labour market experience [17]. On the meso-level pay inequity related with ethnicities appear to be more related to companies' hiring decisions limiting access to jobs, than to their internal wage policies $[18 ; 19]$.

Hawthorne constitutes that the lack of screening pre to migration is a central factor for the negative labour market results of immigrants [20: 7]. According to the data of the Longitudinal Survey of Immigrants to Canada on the micro-level immigrants during their first two years after arriving in Canada perceive their lack of Canadian work experience as well as the recognition of foreign credentials as the biggest obstacles regarding their access to the labour market [21: 29].

Against this background the aim of this paper is the analysis of impact factors of individual wages focusing on migration status.

\section{Theoretical background}

Grant refers to various research studies related to human capital theory, which show the persisting undervaluation of foreign qualifications and work experience leading to higher losses of income for immigrants than in the past $[22 ; 23 ; 24 ; 8]$. Further studies [25, 24] show that the reasons for the income differences are the undervaluation of their credentials as well as the discrimination of immigrants. Overall Grant perceives human capital theory as appropriate to analyse and document the obstacles of an economic integration of immigrants into the labour market [22: 137f]. At the same time it is problematic that there are only few empirical accesses to validate the assumptions of both theories [26: 99].

Generally, human capital can be defined as the stock of competencies, knowledge, and personality attributes, including creativity, embodied in the ability to perform labor so as to produce economic value.

The central postulate of human capital theory $[27 ; 28]$ is that an increasing supply of educational programs is the reaction towards the demand for skilled work. Due to these individuals will try to achieve higher educational degrees until the opportunity costs to reach them exaggerate the benefit related to owning them [28]. It is assumed that education provides skills to individuals, which they use in their employment and which make them a productive and functional member of society. Accordingly individuals who have reached a lower educational level also remain on a lower level of employment [26: 100]. The following figure 1 illustrates the relations respectively effects assumed by human capital theory.

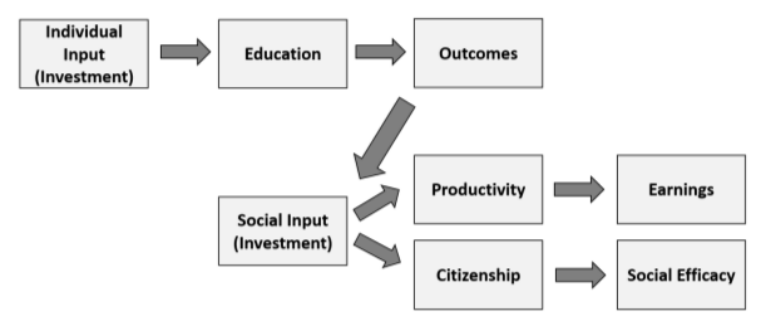

Figure 1. Model of human capital theory [43: 110]

Human capital theory was often questioned regarding its argument that education leads to the acquirement of skills and thereby improves the productivity of individuals $[30 ; 44]$. One central theoretical approach which questions human capital theory is the one of credentialism [26: 102]. The range of credentialism reaches from the assumption that credentials do not contain any information value at all until the assumption that the required educational level needed for a certain job increased over time. For this reason credentialism constitutes a breach towards human capital theory [31: 455]. Credentialism was mainly affected by Collins [32]. According to him there is only a weak relationship between credentials of the educational system and the skills, which are required for an employment. Collins [33] points out the high importance of the labour market regarding the adjustment of the value of education and credentials. He assumes that employers use credentials to give better jobs to better educated employees - but not necessarily because they have better skills or are more productive but because they have more education, which is documented by credentials. This causes the necessity for the educational system to supply better educated individuals. Credentialism is a mechanism of social closure [34] and thereby represents an approach to explain discriminatory recruiting decisions.

Besides the authors of Credentialism also Bourdieu [35]is critical towards the explanatory power of human capital theory regarding aspects of social inequality. Besides economic capital his theory contains the concepts of social capital and cultural capital. Faist [36] defines as follows: „Social capital here means the capacity of individuals to employ (scarce) resources such as information, contacts and money because they are participants and members in social networks and organizations.". The idea of social capital derives from and concretises the network perspective. First Massey and España [37] related the positive effect of social capital to networks of migrants. The concept of social capital is used within an economic aligned migration sociology, which focuses especially on the aspect of embedment into social 
networks [38: 21]. Faist pleads for using social capital analytically at the micro-level as resources of the individual besides economic and cultural capital as an important aspect of migration decisions [36: 29].

Bourdieu extended the economic term of capital to be able to determine a person's social status in a society. He interprets social capital as a resource, which enables an individual to claim a certain position in a social space. From Bourdieu's point of view social capital is something that is accumulated over time [35: 183f.]. He differentiates the following three types of capital:

(1) economic capital: ownership of any goods (enterprises, means of production, property) and any property (money, shares, jewelry, art)

(2) social capital: actual and potential available resources, which derive from the affiliation to and the participation in a social network

(3) cultural capital:

a. objectified: property of material cultural goods like books, music instruments, drawings, machines b. incorporated: cognitive competence; acquired education via the educational measures of the family (primary education) and school education (secondary education)

c. institutionalized: educational degrees and academic titles, which are accredited in credentials/certificates; official recognition of the incorporated cultural capital

[35: 186ff.].

While Bourdieu's theoretical approach distinguishes institutionalized cultural capital (formal qualifications) from incorporated cultural capital (skills), human capital theory does not.

In the context of migration one core question is, if and how well the individual's institutionalized cultural capital (qualifications in terms of diplomas, credentials etc.) and incorporated cultural capital (skills acquired in educational processes or in other learning contexts like on-the-job or in family) can be used to enter the labour market.

Bourdieu's theory of capital provides an analytical access towards the reproduction of inequality within highly individualized societies. This concept can be used to determine the socialstructural positioning of migrants and their habitual dispositions in a differentiated way. The theory describes the state of social groups in a space structured by economic, cultural and social relations of inequality [39; 40: 14]. For the recognition of cultural capital within the conditions of migration the form of the cultural capital is essential. Regarding institutionalized cultural capital (e.g. qualifications/credentials) the recognition can take place formalized, but the national organization of an educational system usually implicates that qualifications/credentials acquired abroad are less well recognized than domestic ones. The problems and obstacles regarding the recognition can derive from various reasons like the unawareness of the acquired qualification in the country of arrival or the differences to a reference qualification or occupation. Incorporated cultural capital (e.g. schemes of thinking and behaviour, language, value orientation, competences) are linked to an individual, who acquired them within a long process of socialization and education [35; 40: 15].

The relationality of this understanding of capital goes along with the fact that a capital's worth can only be determined in relation to the context in which it is embedded and recognized [40: 15]. Still the social space, to which cultural capital is related, is not completely identical with the order of national states [40: 16].

\section{Methodology, data sets and operationalization}

Using a mixed method approach (quantitative analyses, case studies and expert interviews) the complete project identifies approaches and methods that employers and other stakeholders use to make decisions regarding foreign qualification recognition. This paper focuses on parts of the quantitative analyses of the PIAAC data using OLS regression models to investigate if the assumptions of the human capital theory or the theory of credentialism apply to the Canadian labour market. Focusing on variables representing the migration status the analyses compare wages of individuals.

The analyses are conducted using the Canadian PIAAC data set 2012. These data were collected between November 2011 and June 2012. A representative sample of over 27,000 adults aged 16 to 65 across Canada completed the computer-based survey through in-home interviews. Besides this standard survey mode individuals without computer experience had the option to do a paper-and-pencil interview. Samples were selected in sufficient numbers to provide statistically reliable results not only for Canada as a whole, but also for each province and territory. In addition, indigenous peoples, immigrants, and official-language minority populations were oversampled to provide detailed information about these groups (http://www.piaac.ca/). The Canadian data set offers a sample weight, which is used in the following calculations.

Besides sociodemographic characteristics the data set contains information on educational attainment, work experience, cognitive skills, migration status and hourly wages. In the public use file for Canada earnings data are reported only in deciles. Information on the median wage of each decile was obtained and accordingly the decile median was assigned to each respondent belonging to the respective decile. Furthermore PIAAC was especially conducted to collect data about the skills of adults. The PIAAC data set provides information of the individual skill level for the three dimensions literacy, numeracy and problem solving. When using these skill data it is necessary to consider that 
these three dimensions are highly correlated. Within the here reported analyses the respondents' score in numeracy is used because numeracy test items require reading as well as mathematical and reasoning competencies and therefore represent broader cognitive skills than both other dimensions do [41]. Within the OLS regressions the mean value of all ten plausible values for numeracy skills is included in the models.

The estimation sample excludes individuals, who are self-employed, because their qualifications and competences are neither evaluated by an employer nor rewarded by paying them a certain wage. Furthermore the analyses are limited to individuals who work more than 30 hours per week, to have a sample of individuals which have a strong labour-force commitment.

In concrete the presented OLS-regressions use the hourly wages as dependent variable. According to human capital theory, individuals acquire their skills either visiting educational institutions or in the workplace respectively on-the-job. Education is an investment into their human capital and according to the theory leads to a higher income in the labour market. Assuming a competitive labour market an individual's income represents its occupational attainment depending on its abilities and competencies. For respective empirical analyses Mincer developed a regression model [42]. Within his model he develops the statistical relationship between market wages, education and experience. The standard form of the Mincerian wage regression is: $\log y=\log y_{0}+\mathrm{r} S+\beta_{1} X+\beta_{2} X^{2}$, where $\mathrm{y}$ is the income ( $\mathrm{y}_{\mathrm{o}}$ is the income of an individual with no education and no experience), $\mathrm{S}$ is the years of schooling, and $\mathrm{X}$ is years of potential labour market experience.

A basis model referring to this Mincerian wage regression is here used to analyse the determents of individuals' income. Based on this model the next step variables representing the migration status of an individual are successively included in the model to test if they add variance to the prediction of hourly wages. Those variables are the individual's country of birth, the country where the highest qualification was acquired and the parents' country of birth. Within a further model the interaction effect of the individuals' migration status and their work experience is included. As the PIAAC-data set contains a variable, giving information about the region, where the respondents acquired their highest qualification, an interaction effect between the migration status and the educational attainment of the individuals is not necessary to consider. For all models robust standard errors are calculated.

Besides the considered aspects in the regression models it can be assumed that the industry in which the employees work influences their income as well. To investigate this assumption multilevel models are calculated for the three variables years of education, years of work experience as well as numeracy skills. These calculations provide insights how these three variables influence the individual income on an individual level (level 1) as well as on an industry level (level 2). The PIAAC data set contains two different variables categorizing industries - the International Standard Industrial Classification (ISIC) and the North American Industry Classification System (NAICS). Generally both classifications could be used for the analyses. Within the following the ISIC will be used, because it allows for international comparisons, which will be relevant later in the project.

\section{Results}

The data (all reported with weights) show some minor discrepancies for the above sample from the full sample. While the share of females is $50.0 \%$ in the full sample it is only $44.62 \%$ in the analysed one. The share of respondents born abroad, which is $25.31 \%$, is comparable to the share in the full sample (25.76\%). Furthermore $15.43 \%$ of respondents in the analysed sample acquired their highest qualification outside of Canada, while this is the case for a share of $15.86 \%$ of the full sample. The following Table 1 gives an overview of the means and standard deviations of selected variables used in the analyses.

Table 1. Selected descriptive statistics

\begin{tabular}{|l|l|l|}
\hline Variable & Mean & Std. dev. \\
\hline Gross hourly wage (CAD) & 25.07 & 11.21 \\
\hline Years of education & 14.49 & 3.39 \\
\hline Years of work experience & 18.93 & 11.65 \\
\hline Numeracy skills & 267.79 & 49.85 \\
\hline n=12,937; weighted; Data source: PIAAC 2012. \\
\hline
\end{tabular}

The calculated base model 1 referring to the Mincerian wage regression explains about $28 \%$ of the variance of hourly wages. All variables included have significant effects. Being female has a negative influence (-0.141), while a higher educational attainment has a positive effect (0.055). Regarding the work experience the calculated model confirms the assumption of the Mincerian model, which presumes a positive effect of the years of work experience (0.031) and a negative effect of the squared years of work experience, here multiplied by 100 (-0.050). Table 2 shows this model as well as all further models. which take into account individual numeracy skills, variables representing the respondents' migration status and finally interaction effects between educational attainment, work experience and skills with the migration status. 
Table 2. Wage effects of education, work experience, skills and migration status

\begin{tabular}{|c|c|c|c|c|c|}
\hline & \multicolumn{5}{|c|}{ Model } \\
\hline & 1 & 2 & 3 & 4 & 5 \\
\hline Gender & $\begin{array}{c}.141 \\
(.011) \\
\end{array}$ & $\begin{array}{l}-.103 \\
(.011) \\
\end{array}$ & \begin{tabular}{l|}
.105 \\
$(.011)$ \\
\end{tabular} & $\begin{array}{l}-.106 \\
(.011) \\
\end{array}$ & $\begin{array}{l}.110 \\
(.011) \\
\end{array}$ \\
\hline Years of education & $\begin{array}{l}.055 \\
(.002) \\
\end{array}$ & $\begin{array}{l}.038 \\
(.002) \\
\end{array}$ & $\begin{array}{l}.039 \\
(.002) \\
\end{array}$ & $\begin{array}{l}.039 \\
(.002)\end{array}$ & $\begin{array}{l}.045 \\
(.002) \\
\end{array}$ \\
\hline Years of work experience & $\begin{array}{l}.031 \\
(.002)\end{array}$ & $\begin{array}{l}.030 \\
(.002)\end{array}$ & $\begin{array}{l}.030 \\
(.002)\end{array}$ & $\begin{array}{l}.031 \\
(.002)\end{array}$ & $\begin{array}{l}.031 \\
(.002)\end{array}$ \\
\hline $\begin{array}{l}\text { Years of work } \\
\text { experience }^{2} * 100\end{array}$ & $\begin{array}{l}-.050 \\
(.004)\end{array}$ & $\begin{array}{l}-.045 \\
(.004)\end{array}$ & $\begin{array}{l}.046 \\
(.004)\end{array}$ & $\begin{array}{l}-.048 \\
(.004)\end{array}$ & $\begin{array}{l}.048 \\
(.004)\end{array}$ \\
\hline $\begin{array}{l}\text { Numeracy (mean of } \\
\text { plausible values)*100 }\end{array}$ & - & $\begin{array}{l}.249 \\
(.013)\end{array}$ & $\begin{array}{l}.235 \\
(.013)\end{array}$ & $\begin{array}{l}.224 \\
(.014)\end{array}$ & $\begin{array}{l}.209 \\
(.016)\end{array}$ \\
\hline Born abroad & - & - & $\begin{array}{l}.051 \\
(.014) \\
\end{array}$ & $\begin{array}{l}.004 \\
(.019)\end{array}$ & $\begin{array}{l}.028 \\
(.021) \\
\end{array}$ \\
\hline $\begin{array}{l}\text { Highest qual. acqu. in } \\
\text { Canada (ref. category) }\end{array}$ & - & - & - & - & - \\
\hline $\begin{array}{l}\text { Arab States and Sub- } \\
\text { Saharan Africa }\end{array}$ & - & - & - & $\begin{array}{l}.166 \\
(.056)\end{array}$ & $\begin{array}{l}-.170 \\
(.056)\end{array}$ \\
\hline $\begin{array}{l}\text { Latin America and the } \\
\text { Caribbean }\end{array}$ & - & - & - & $\begin{array}{l}-.208 \\
(.036) \\
\end{array}$ & $\begin{array}{l}-.221 \\
(.037) \\
\end{array}$ \\
\hline Asia and the Pacific & - & - & - & $\begin{array}{l}.110 \\
(.027) \\
\end{array}$ & $\begin{array}{l}.120 \\
(.028)\end{array}$ \\
\hline $\begin{array}{l}\text { Central and Eastern } \\
\text { Europe }\end{array}$ & - & - & - & $\begin{array}{l}-.130 \\
(.043)\end{array}$ & $\begin{array}{l}.132 \\
(.044)\end{array}$ \\
\hline $\begin{array}{l}\text { North America and } \\
\text { Western Europe }\end{array}$ & - & - & - & $\begin{array}{l}.010 \\
(.032) \\
\end{array}$ & $\begin{array}{l}.003 \\
(.032) \\
\end{array}$ \\
\hline $\begin{array}{l}\text { Years of education*born } \\
\text { abroad }\end{array}$ & - & - & - & 一 & $\begin{array}{l}-.016 \\
(.004) \\
\end{array}$ \\
\hline $\begin{array}{l}\text { Years of work exp.*born } \\
\text { abroad }\end{array}$ & - & 一 & - & - & $\begin{array}{l}.000 \\
(.001)\end{array}$ \\
\hline $\begin{array}{l}\text { Numeracy skills*born } \\
\text { abroad }\end{array}$ & & & & & $\begin{array}{l}.038 \\
(.029)\end{array}$ \\
\hline Constant & $\begin{array}{l}3.099 \\
(.009)\end{array}$ & $\begin{array}{l}3.066 \\
(.009)\end{array}$ & $\begin{array}{l}3.080 \\
(.009)\end{array}$ & $\begin{array}{l}3.082 \\
(.009)\end{array}$ & $\begin{array}{l}3.082 \\
(.009)\end{array}$ \\
\hline R-squared & .277 & .335 & .337 & .343 & .346 \\
\hline
\end{tabular}


In model 2 the mean plausible value for the dimension numeracy is included in the model. The results show that including the respondents' score in numeracy adds further variance to the model (0.335 in comparison to 0.277) and that higher individual numeracy skills have a positive income effect $(0.249)$.

To operationalize the individuals' migration status different variables can be used and were considered. Within the respective presented models the country of birth as well as the region, where the highest qualification has been acquired, have been used. Besides this also the parent's status of migration or the migration program under which the individual came to Canada could potentially be used. Calculating a model using the parents' migration status showed that this variable explains the smallest additional variance in comparison to the country of birth and the region, where the highest qualification has been acquired. Regarding the migration programs it is problematic, that the data set contains respective information only for a very limited amount of respondents.

Considering all this in model 3 first the country of birth was included. This variable adds only little variance to model 2 (0.335 in comparison to 0.337 ). Furthermore the negative effect of being born in another country than Canada (-0.051) is statistically significant in this model. The other effects stay comparatively constant. In model 4 instead of the country of birth the region where the respondents attained their highest qualification is included. This variable adds comparatively more variance than the respondents' country of birth does $(0.337$ in comparison to 0.343 ). The results show that the acquirement of the highest qualification outside of Canada has a negative income effect for all regions except North America and Western Europe. However, among the other regions there is variance - the following regions have slightly sloping negative income effects: Asia and the Pacific (0.110), Central and Eastern Europe (-0.130), Arab States and Sub-Saharan Africa (-0.166), Latin America and the Caribbean (-0.208). Different from these regions there is no income penalty for people who have acquired their highest qualification in North America or Europe. Actually, the positive coefficient calculated is not statistically significant. Furthermore, in model 4, when including the regions where the highest qualification has been acquired the country of birth outside Canada is no longer statistically significant.

Finally in model 5 interaction effects between the migration status (being born abroad) and the variables years of education, years of work experience as well as numeracy skills are taken into account. The results show that there is a negative interaction effect between the country of birth (outside Canada) and the individual years of education. The two other interaction effects are not statistically significant, whereas the one between country of birth and numeracy skills is positive.
In a next step the effects of the industry, in which the individuals work, is considered as a relevant aspect influencing their income. In order to prove this using the ISIC-classification the following industry specific income data are calculated (see Table 3).

Table 3. Income data sorted by industries (gross hourly wage in CAD)

\begin{tabular}{|c|c|c|c|}
\hline Industry & Obs. & Mean & $\begin{array}{l}\text { Std. } \\
\text { Dev. }\end{array}$ \\
\hline $\begin{array}{l}\text { Agriculture, forestry } \\
\text { and fishing }\end{array}$ & 208 & 16.84 & 7.34 \\
\hline Mining and quarrying & 285 & 35.12 & 11.12 \\
\hline Manufacturing & 1,417 & 24.72 & 10.45 \\
\hline $\begin{array}{l}\text { Electricity, gas, steam } \\
\text { and air conditioning } \\
\text { supply }\end{array}$ & 135 & 39.10 & 9.19 \\
\hline $\begin{array}{l}\text { Water supply; } \\
\text { sewerage, waste } \\
\text { management and } \\
\text { remediation act }\end{array}$ & 87 & 25.51 & 10.00 \\
\hline Construction & 875 & 25.51 & 9.74 \\
\hline $\begin{array}{l}\text { Wholesale and retail } \\
\text { trade; repair of motor } \\
\text { vehicles and } \\
\text { motorcycles }\end{array}$ & 1,661 & 20.20 & 10.26 \\
\hline $\begin{array}{l}\text { Transportation and } \\
\text { storage }\end{array}$ & 601 & 23.34 & 9.17 \\
\hline $\begin{array}{l}\text { Accommodation and } \\
\text { food service activities }\end{array}$ & 561 & 14.47 & 5.75 \\
\hline $\begin{array}{l}\text { Information and } \\
\text { communication }\end{array}$ & 455 & 30.42 & 11.58 \\
\hline $\begin{array}{l}\text { Financial and } \\
\text { insurance activities }\end{array}$ & 599 & 29.62 & 10.66 \\
\hline Real estate activities & 126 & 22.24 & 10.28 \\
\hline $\begin{array}{l}\text { Professional, scientific } \\
\text { and technical } \\
\text { activities }\end{array}$ & 547 & 27.84 & 11.79 \\
\hline $\begin{array}{l}\text { Administrative and } \\
\text { support service } \\
\text { activities }\end{array}$ & 407 & 19.24 & 8.79 \\
\hline $\begin{array}{l}\text { Public administration } \\
\text { and defence; } \\
\text { compulsory social } \\
\text { security }\end{array}$ & 1,458 & 32.68 & 9.67 \\
\hline Education & 1,127 & 29.77 & 10.39 \\
\hline $\begin{array}{l}\text { Human health and } \\
\text { social work activities }\end{array}$ & 1,644 & 25.81 & 10.53 \\
\hline $\begin{array}{l}\text { Arts, entertainment } \\
\text { and recreation }\end{array}$ & 191 & 23.69 & 10.75 \\
\hline $\begin{array}{l}\text { Other service } \\
\text { activities }\end{array}$ & 231 & 22.09 & 11.84 \\
\hline $\begin{array}{l}\text { Activities of house- } \\
\text { holds as employers; } \\
\text { undifferentiated good }\end{array}$ & 32 & 14.63 & 6.33 \\
\hline
\end{tabular}

The results show that there is a big variance between means of each industry. One can see that there is a difference in mean wages of $24.63 \mathrm{CAD}$ 
between the highest paying industry "Electricity, gas, steam and air conditioning supply" (39.10 CAD) and the lowest paying industry "Accommodation and food service activities" (14.47 CAD). The respective t-test proves the significance of this result (t-value: 4.500; significance: $p<0.001)$. The occurring differences regarding the income result from individual characteristics as well as from industry specific characteristics. Within all the above regression models only variables representing individual characteristics have been included. In the following model the industry in which the respondents work is regarded as one more individual characteristic. The following Table 4 shows the results of the respective model.

Table 4. Wage effects of education, work experience, skills, migration status and industry

\begin{tabular}{|c|c|c|c|}
\hline Independent Variable & Coeff. & Rob. St. Er. & Sig. \\
\hline Gender & -.117 & .011 & .000 \\
\hline Years of education & .036 & .002 & .000 \\
\hline Years of work experience & .027 & .002 & .000 \\
\hline Years of work experience ${ }^{2 *} 100$ & -.042 & .004 & .000 \\
\hline Numeracy (mean of plausible values) $* 100$ & .180 & .015 & .000 \\
\hline Born abroad & .035 & .018 & .059 \\
\hline \multicolumn{4}{|l|}{ Highest qual. acqu. in Canada (ref. category) } \\
\hline Arab States and Sub-Saharan Africa & -.151 & .054 & .006 \\
\hline Latin America and the Caribbean & -.182 & .033 & .000 \\
\hline Asia and the Pacific & -.092 & .026 & .000 \\
\hline Central and Eastern Europe & -.136 & .041 & .001 \\
\hline North America and Western Europe & .003 & .028 & .921 \\
\hline Years of education*born abroad & -.015 & .003 & .000 \\
\hline Years of work exp.*born abroad & -.000 & .001 & .709 \\
\hline Numeracy skills*born abroad & .025 & .026 & .336 \\
\hline Agriculture, forestry and fishing & .084 & .041 & .041 \\
\hline Mining and quarrying & .635 & .040 & .000 \\
\hline Manufacturing & .305 & .026 & .000 \\
\hline Electricity, gas, steam and air conditioning supply & .656 & .042 & .000 \\
\hline Water supply; sewerage, waste management and remediation act & .265 & .084 & .000 \\
\hline Construction & .388 & .032 & .000 \\
\hline Wholesale and retail trade; repair of motor vehicles and motorcycles & .152 & .027 & .000 \\
\hline Transportation and storage & .286 & .032 & .000 \\
\hline \multicolumn{4}{|l|}{ Accommodation and food service activities } \\
\hline Information and communication & .432 & .035 & .000 \\
\hline Financial and insurance activities & .458 & .029 & .000 \\
\hline Real estate activities & .170 & .065 & .000 \\
\hline Professional, scientific and technical activities & .364 & .033 & .000 \\
\hline Administrative and support service activities & .141 & .038 & .000 \\
\hline Public administration and defence; compulsory social security & .523 & .028 & .000 \\
\hline Education & .405 & .029 & .000 \\
\hline Human health and social work activities & .398 & .027 & .000 \\
\hline Arts, entertainment and recreation & .212 & .042 & .000 \\
\hline Other service activities & .132 & .053 & .013 \\
\hline Activities of house-holds as employers; undifferentiated good & .054 & .096 & .576 \\
\hline Constant & 2.770 & .024 & .000 \\
\hline R-squared & .441 & & \\
\hline
\end{tabular}


Including industry as an independent variable in the model adds a significant share of variance in comparison to the above models. For example, in comparison to model 5, which explains $35 \%$ variance, the model including the industries explains $44 \%$ variance of the individual income. In the model the lowest paying industry, which is "Accommodation and food service activities", was used as reference category. As expected the effects for all other industries are positive. According to the descriptive data the coefficient of the best paying industry "Electricity, gas, steam and air conditioning supply" has the highest value (0.621). Except for the industries "Agriculture, forestry and fishing", "Mining and quarrying" as well as "Activities of households as employers; undifferentiated goods- and services-producing activities of households for own use" all effects are statistically significant.

As an alternative to the OLS-regression model including the industries as independent variables the influences of the industry on income can also be analysed by calculating multilevel models instead. In this case industry is not regarded as an individual characteristic but as a group variable. Another advantage of this model is that it allows an exact calculation of the variance explained on each level. Here the multilevel models are mainly used to illustrate the effects of the three not migrationrelated and metric variables explaining individual income: years of education, years of work experience as well as numeracy skills. The results illustrate the part of the variance of income, which can be explained on an individual level (level 1), and the part of the variance of income, which can be explained on an industry level (level 2) for each of these three variables.

To check if there is variance in the individual income, which can be explained by the industries first a null model is calculated. In this model the variance of the constant explained on the industry level is 0.069 and the respective ICC-value (IntraClass-Correlation) is 0.307 . The ICC tells us that 30.7 percent of the overall variance are explained by level 2 (the industry). This result shows that the calculation of further models considering the industry as a second level makes sense. In a further step random intercept models for the above three variables were calculated to see how the variance of income is related to the individual level and the industry level. The following Table 5 gives an overview of the results.

The results show that for all three level 1 variables there is a significant part of variance which can be explained on level 2 (industry level). The multi level model shows that $5.2 \%$ of the variance of the constant is explained on level 2, which means by the industry, for the level 1 variable years of education. For years of work experience the respective value is $6.5 \%$ and for numeracy skills $4.8 \%$ can be explained on level 2 . The ICC values for all models also indicate that a significant part of the variance of individual income can be explained by the industry, which legitimates the calculation of the above multi level models.

Table 5. Results of the random intercept models for one variable each

\begin{tabular}{|l|l|l|l|}
\hline $\begin{array}{l}\text { Independent } \\
\text { Variable }\end{array}$ & $\begin{array}{l}\text { Years of } \\
\text { education }\end{array}$ & $\begin{array}{l}\text { Years of } \\
\text { work } \\
\text { exp. }\end{array}$ & $\begin{array}{l}\text { Numeracy } \\
\text { skills }\end{array}$ \\
\hline Coefficient & .040 & .007 & .275 \\
\hline Constant & 3.069 & 3.071 & 3.067 \\
\hline $\begin{array}{l}\text { Variance of } \\
\text { constant on } \\
\text { level 2 }\end{array}$ & .052 & .065 & .048 \\
\hline $\begin{array}{l}\text { Variance of } \\
\text { residual on } \\
\text { level 2 }\end{array}$ & .141 & .149 & .140 \\
\hline $\begin{array}{l}\text { Log- } \\
\text { Likelihood }\end{array}$ & 5617.7 & 5967.6 & 5541.7 \\
\hline Wald-Chi2 & 1376.5 & 621.2 & 1546.4 \\
\hline P(Wald-Chi2) & .000 & .000 & .000 \\
\hline $\begin{array}{l}\text { ICC value } \\
.270\end{array}$ & .302 & .257 \\
\hline $\begin{array}{l}\text { n=12,647; groups: } 20 ; \text { weighted data; } \\
\text { PIAAC 2012 }\end{array}$ & data source: \\
\hline
\end{tabular}

To visualise the effects of the three analysed level 1 variables on the industry level (level 2) the calculated random intercept models are transformed into graphs. The following figure 3 shows the respective results. Each graph shows the regression lines for a model with the income as dependent variable and the years of education, the years of work experience and the numeracy skills as the independent variable. Due to the multi level approach the graphs show one regression line for each industry, which illustrates the effect of industry on level 2 well visible.

When comparing the three graphs there are some striking results and differences. Overall it becomes apparent that all three variables have a positive effect on the individual income.

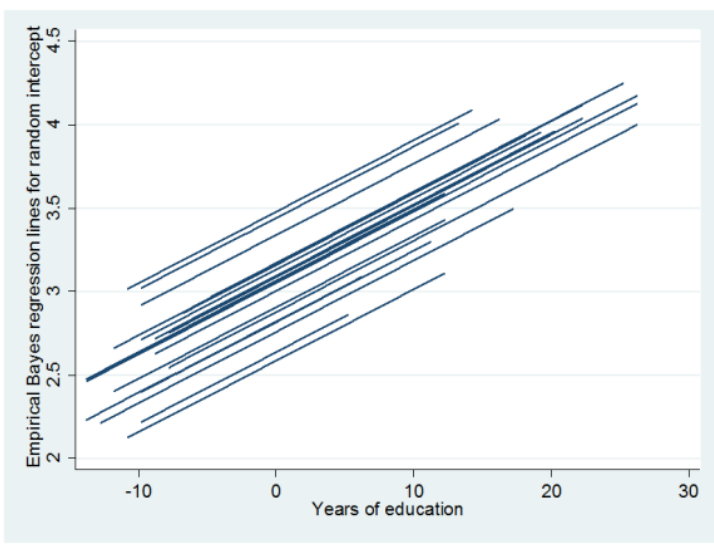




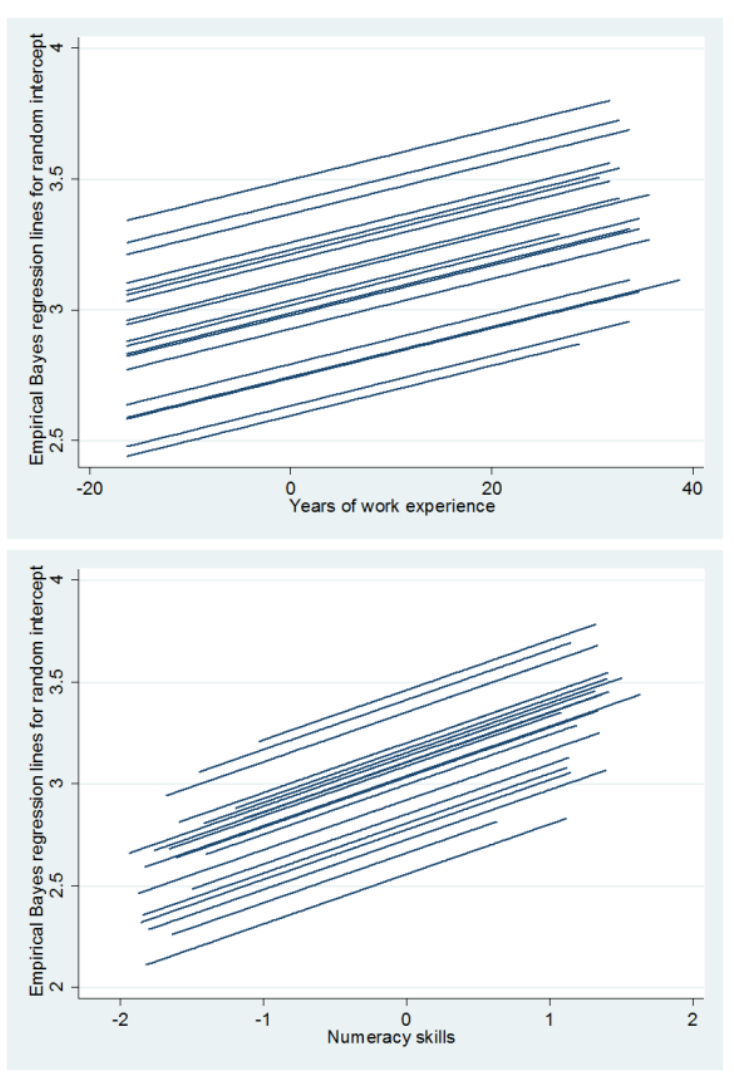

Figure 3. Random intercepts on industry level for years of education, years of work experience and numeracy skills $\mathrm{n}=12,647$; data source: PIAAC 2012

This proves the results of all the above regression models. The graphs furthermore visualise that the years of education as well as the numeracy skills explain a bigger part of variance of income on an individual level than the years of work experience do. When calculating univariate regression models with only the years of education as independent variable the variance explained is $15.6 \%$, while with numeracy skills as independent variable the variance explained is even $16.9 \%$. The years of work experience explain a smaller part of variance of income on an individual level, which is visible when comparing the above graphs. The respective univariate regression model for years of work experience explains $4.8 \%$ of the variance of individual income. These results confirm the results of the multivariate regression models. The additional information gained by calculating the multi level models is to get insights on how the industry affects the income and how the level of income differs among industries.

Regarding the industry level the calculated models as well as the graphs show that for all three variables there is variance. The calculated values of the models prove that the biggest share of variance on level 2 occurs regarding the variable years of work experience. This can also be seen very well when comparing the three above graphs, because for this variable the calculated regression lines for all 20 industries show the strongest variation.

Finally a random intercept model with all three variables included has been calculated. This leads to the following results (see table 6). It shows that even when including all variables at once on level 1 there is still 23.4 percent of variance explained on level 2.

Table 6. Results of the random intercept model for three variables

\begin{tabular}{|c|c|c|c|}
\hline \multicolumn{4}{|l|}{ Fixed effects } \\
\hline & Coeff. & $\begin{array}{l}\text { Std. } \\
\text { Error }\end{array}$ & Sign. \\
\hline Years of education & .030 & .001 & .000 \\
\hline Years of work exp. & .009 & .000 & .000 \\
\hline Numeracy skills & .203 & .007 & .000 \\
\hline Constant & 3.036 & .044 & .000 \\
\hline \multicolumn{4}{|c|}{ Components of variance } \\
\hline & \multicolumn{2}{|l|}{ Coeff. } & Std. Error \\
\hline $\begin{array}{l}\text { Variance of constant } \\
\text { on level } 2\end{array}$ & \multicolumn{2}{|l|}{.038} & .012 \\
\hline $\begin{array}{l}\text { Variance of residual } \\
\text { on level } 2\end{array}$ & \multicolumn{2}{|l|}{.123} & .002 \\
\hline Log-Likelihood & \multicolumn{3}{|l|}{-4761.7} \\
\hline Wald-Chi2 & \multicolumn{3}{|l|}{3410.8} \\
\hline P(Wald-Chi2) & \multicolumn{3}{|l|}{.000} \\
\hline ICC value & \multicolumn{3}{|l|}{.234} \\
\hline \multicolumn{4}{|c|}{$\mathrm{n}=12,647 ;$ data source: PIAAC 2012} \\
\hline
\end{tabular}

\section{Conclusion and forecast}

The Mincer regression model and its assumptions could be fully replicated in the above calculations. Accordingly, years of education as well as work experience represent two very important variables influencing individuals' income. Furthermore, the PIAAC data set allows to estimate the influence of individual skills, which shows that numeracy skills (which were chosen here in the models) explain additional variance of wages. Besides these important aspects determining the income the focus of this paper was to analyze to which extent the individuals' migration status affects their income.

Overall the findings confirm the discrimination of immigrants on the Canadian labour market regarding their income due to the foreign acquirement of their qualifications. But the data only prove the devaluation of qualifications acquired abroad. In concrete the results suggest that the region where the highest qualification was acquired determines the migrants' income more than the fact that they were born in another country than Canada. Furthermore, the identified interaction effect between years of education and migration status (being born abroad) also indicates that 
education is devaluated on the Canadian labour market if individuals have a migration background.

Besides all the above individual characteristics one further aspect is considered in a second step of the analyses: the influence of the industry on the individual income. Here all results prove the strong role industries play in determining the individual income. The respective results are consistent no matter if the industry is regarded as an individual characteristic or as a group variable on a second level. Regarding this second level it would be interesting to include further variables in the model characterising the industry like unemployment quota, value added, share of gross domestic product etc. These data are not available in the PIAAC data set, because it only contains individual data which was collected from the respondents. In a further step respective data could be merged from other data sets.

Finally, the results indicate the explanatory power of the above theories towards the entrance to the labour market and the meaning of educational credentials and work experience for immigrants. In concrete the results suggest that the acquisition of the highest qualification outside of Canada is a stronger disadvantage on the Canadian labour market than being born outside of Canada, judging by the achieved hourly wage. Furthermore, the results prove a wage penalty for foreign qualifications, while they do not prove this for foreign work experience. Here the differentiated approach from Bourdieu seems more useful than human capital theory, because the results prove that there are differences of international transferability between different kinds of cultural capital in the terms of Bourdieu.

The analysis has some limitations, which have to be considered when interpreting the results. The operationalisation of the migration status as described above is possible by using various variables. But the calculated models already show that when including more than one of these variables the effects may get smaller or even lose their significance. Finally, the actuality of data set has to be considered.

The conducted analyses could prove the discrimination of immigrants in the Canadian labour market already discovered within former research. But the results only document the actual status quo and do not provide explanations why this situation occurs. In order to find answers to this question the project will focus on investigating the reasons for the discrimination of migrants by conducting case studies in Canadian enterprises as a next step. Using a maximum variation sampling the health and ICT sectors will be analysed. While the health sector is characterised by a high level of standardization and regulation, in which qualifications and credentials play a big role, this is less the case for the ICT sector. The case studies furthermore serve to identify approaches and methods that employers and other stakeholders use to make decisions regarding foreign qualification recognition.

\section{References}

[1] Walker, A., (2007): Constructing Problems and Solutions: The Social Construction of Foreign Credential Recognition as a Social Problem and Policy Priority in Canada. Open Access Dissertations and Theses. Paper 5678.

[2] Guo, S., Shan, H., (2013): Canada. In: International Organization for Migration: Recognition of qualifications and competences of migrants. Brussels. pp. 228-253.

[3] Green, D. A., (1999): Immigrant occupational attainment. Assimilation and mobility over time. In: Journal of Labor Economics. Volume 17, Issue 1. pp. 4979.

[4] Li, Q., Sweetman, A., (2013): The Quality of Immigrant Source Country Educational Outcomes: Do they Matter in the Receiving Country? In: Centre for Research and Analysis of Migration: Discussion Paper Series, CDP No. 32/13.

[5] Picot, G./Sweetman, A., (2012): Making It in Canada: Immigration Outcomes and Policies. IRPP Study 29. Montreal.

[6] Sweetman, A., McBride, S. (2004): Postsecondary Field of Study and the Canadian Labour Market Outcomes of Immigrants and Non-Immigrants. Analytical Studies Branch research paper series, Statistics Canada, no 233, pp. 1-70.

[7] Picot, G./Hou, F., (2003): The Rise in Low-Income Rates among Immigrants in Canada. In: Statistics Canada: Business and Labour Market Analysis Division (Eds.): Analytical Studies Branch research paper series. 11F0019MIE - No. 198. Ottawa.

[8] Picot, G. (2004): Immigrant Patterns and Deteriorating Labour Market Outcomes 1980-2000: The Canadian Story. In: Statistics Canada: Business and Labour Market Analysis Division (Eds.): Analytical Studies Branch research paper series. 11F0019MIE - No. 222. Ottawa.

[9] Thompson, E., Worswick, C., (2004): Canadian Research on Immigration and the Labour Market: An Overview. Human Resources and Skills Development Canada. Ottawa.

[10] Reitz, J. G., (2005): Tapping Immigrants' Skills: New Directions for Canadian Immigration Policy in the knowledge Economy. In: IRPP Choices. Volume 11, No.

[11] Leuven, E., Oosterbeek, H., (2011): Overeducation and Mismatch in the Labor Market. In: Handbook of the Economics of Education, Volume 4, pp. 283-326.

[12] Li, P., (2008): The role of foreign credentials and ethnic ties in immigrants' economic performance. In: Canadian Journal of Sociology. Volume 33, Issue 2. pp. 291-310. 
[13] Green, D., Worswick, C., (2012): Immigrant earnings profiles in the presence of human capital investment: measuring cohort and macro effects. In: Labour Economics. Volume 19, Issue 2. pp. 241-259.

[14] Schaafsma, J., Sweetman, A., (2001): Immigrant earnings. Age at immigration matters. In: Canadian Journal of Economics. Volume 34, Issue 4. pp. 10661099.

[15] Aydemir, A., Skuterud, M., (2005): Explaining the deteriorating entry earnings of Canada's immigrant cohorts, 1966-2000. In: Canadian Journal of Economics. Volume 38, Issue 2. pp. 641-672.

[16] Owen, T., Lowe, S. J., (2008): Labour Market Integration of Skilled Immigrants: Good Practices for the Recognition of International Credentials: Canada.

[17] Warman, C., Sweetman, A., Goldmann, G., (2015): The Portability of New Immigrants' Human Capital: Language, Education, and Occupational Skills. Canadian Public Policy/Analyse de politiques 41 (Supplement 1): pp. 64-S79.

[18] Sweetman, A., McDonald, J.T., Hawthorne, L., Occupational Regulation and Foreign Qualification Recognition: An Overview. Canadian Public Policy, Volume 41, Supplement 1, August 2015, pp. S1-S13.

[19] Owusu, Y., Sweetman, A., (2015): Regulated Health Professions: Outcomes by Place of Birth and Training. Canadian Public Policy 41, Supplement 1, pp. 98-115.

[20] Hawthorne, L., (2007): Foreign credential recognition and assessment: An introduction. In: Canadian Issues. Spring 2007. S. 3-13.

[21] Kustec, S., Thompson, E., Xue, L., (2007): Foreign Credentials: The Tools for Research. In: Canadian Issues. Spring 2007. S. 26-30.

[22] Grant, P. R., (2007): The Inclusion of Skilled Migrants into the Canadian Labour Market: Research Relevant to the Development of More Person-Centred Policies. In: Canadian Issues. Spring 2007. S. 137-140.

[23] Grant, H., Sweetman, A., (2004): Introduction to Economic and Urban Issues in Canadian Immigration Policy. In: Canadian Journal of Urban Research. Band 13. S. $1-24$

[24] Li, P., (2003): Destination Canada: Immigration debates and Issues. Toronto.

[25] Reitz, J. G., (2001): Immigrant skill utilization in the Canadian labour market: Implications of human capital research. In: Journal of International Migration and Integration. Band 2, Heft 3. S. 347-378.

[26] Walters, D., (2004): The Relationship Between Postsecondary Education and Skill: Comparing Credentialism with Human Capital Theory. In: Canadian Journal of Higher Education. Volume 34, Issue 2. S. $97-$ 124

[27] Becker G.S., (1964) Human capital: A theoretical and empirical analysis, with special reference to education. New York.
[28] Schultz, T.W., (1961): Investment in human capital. In: American Economic Review. Band 51. S. 1-17.

[29] Livingstone, D. W., (2001): Adults' Informal Learning: Definitions, findings, gaps and future research. NALL Working Paper 21. Toronto.

[30] Wolf, A., (2002): Does education matter: Myths about education and economic growth. New York.

[31] Bills, D., (2003): Credentials, Signals, and Screens: Explaining the Relationship Between Schooling and Job Assignment. In: Review of Educational Research. University of Iowa. Volume 73, Issue 4. S. 441-469.

[32] Collins, R., (1979): The Credential Society: An Historical Sociology of Education and Stratification. New York.

[33] Collins, R., (1988): Theoretical Sociology. New York.

[34] Weeden, K., Grusky, D.B., (2012): The Three Worlds of Inequality. In: American Journal of Sociology. Volume 117, Issue 6. pp. 1723-1785.

[35] Bourdieu, P., (1983): Ökonomisches Kapital, kulturelles Kapital, soziales Kapital. In Reinhard Kreckel (Hrsg.): Soziale Ungleichheiten (Soziale Welt, Sonderband 2). S.183-198. Göttingen.

[36] Faist, T., (1995): Sociological Theories of International Migration: The Missing Meso-Link. Paper presented at the Meeting of the Theory Group of Migration and Development (MAD) Project, Hamburg, ZeS-Arbeitspapier, 17.

[37] Massey, D. S., España, F. G., (1987): The Social Process of International Migration; in: Science, p. 733738

[38] Haug, S., (2000): Soziales Kapital und Migration. In: Schriftenreihe des Bundesinstituts für Bevölkerungsforschung, Opladen.

[39] Bourdieu, P., (1982): Die feinen Unterschiede. Kritik der gesellschaftlichen Urteilskraft. Frankfurt am Main.

[40] Nohl, A.-M., Schittenhelm, K., Schmidtke, O., Weiß, A., (2006): Kulturelles Kapital in der Migration ein Mehrebenenansatz zur empirisch-rekonstruktiven Analyse der Arbeitsmarkintegration hochqualifizierter MigrantInnen Forum Qualitative Sozialforschung, 7(3), Art. 14, URL: http://nbnresolving.de/urn:nbn:de:0114fqs0603143.

[41] Velten, S., Ebner, C.: General competencies or certificates? Wage determination for complex tasks in Germany. Paper presented at the ECER 2016. Dublin.

[42] Mincer, J., (1974): Schooling, Experience, and Earnings. National Bureau of Economic Research. New York.

[43] Swanson, R.A., Holton, E.F., (2001). Foundations of human resource development. San Francisco: BerrettKoehler. 
International Journal of Innovative Business Strategies (IJIBS), Volume 3, Issue 1, June 2017

[44] Livingstone D.W., (1998): The education-jobs gap:

Underemployment or economic democracy. Toronto. 